\title{
Paenibacillus alkaliterrae sp. nov., isolated from an alkaline soil in Korea
}

Correspondence

Jung-Hoon Yoon

jhyoon@kribb.re.kr
The genus Paenibacillus was proposed by reclassification of 11 Bacillus species by Ash et al. (1993). Since the description of the genus, continuous reclassifications of some other Bacillus species and descriptions of new species have increased considerably the number of species belonging to the genus Paenibacillus (for example Heyndrickx et al., 1996; Shida et al., 1997a, b; Pettersson et al., 1999; Roux \& Raoult, 2004). At the time of writing, the genus Paenibacillus comprises at least 60 species with validly published names, including the recently described species Paenibacillus xylanilyticus (Rivas et al., 2005a), Paenibacillus phyllosphaerae (Rivas et al., 2005b), Paenibacillus hodogayensis (Takeda et al., 2005), Paenibacillus barcinonensis (Sánchez et al., 2005) and Paenibacillus rhizosphaerae (Rivas et al., 2005c). In this study, we report on the taxonomic characterization of a Paenibacillus-like bacterial strain, KSL$134^{\mathrm{T}}$, which was isolated from an alkaline soil in Korea.

Published online ahead of print on 22 July 2005 as DOI 10.1099/ ijs.0.63771-0.

The GenBank/EMBL/DDBJ accession number for the $16 \mathrm{~S}$ rRNA gene sequence of strain KSL-134 ${ }^{\top}$ is AY960748.

A neighbour-joining tree based on $16 \mathrm{~S}$ rRNA gene sequences showing the phylogenetic positions of Paenibacillus alkaliterrae KSL-134 $4^{\top}$, Paenibacillus species and representatives of some other related taxa is available as supplementary data in IJSEM Online.
Strain KSL-134 ${ }^{\mathrm{T}}$ was isolated by the standard dilution plating technique at $30{ }^{\circ} \mathrm{C}$ on 10 -fold diluted nutrient agar (NA; Difco) with $\mathrm{pH}$ adjusted to 9・0. Paenibacillus glycanilyticus KCTC $3808^{\mathrm{T}}$, Paenibacillus agarexedens KCTC $3848^{\mathrm{T}}$ and Paenibacillus agaridevorans KCTC $3849^{\mathrm{T}}$, which were used as reference strains for DNA-DNA hybridization and some physiological characterization, were obtained from the Korean Collection for Type Cultures, Taejon, Korea. To investigate its morphological and physiological characteristics, strain KSL- $134^{\mathrm{T}}$ was routinely cultivated at $30^{\circ} \mathrm{C}$ on twofold diluted NA with $\mathrm{pH}$ adjusted to 7·5. Cell morphology was examined by light microscopy (Nikon E600) and transmission electron microscopy (TEM). Presence of flagella was examined by TEM using cells from exponentially growing cultures. Gram reaction was determined using the bioMérieux Gram Stain kit according to the manufacturer's instructions. Growth at various temperatures $\left(4-45^{\circ} \mathrm{C}\right)$ was measured on twofold diluted NA ( $\mathrm{pH} 7 \cdot 5)$. Growth at $5 \%(\mathrm{w} / \mathrm{v}) \mathrm{NaCl}$ concentration was investigated in twofold diluted NA ( $\mathrm{pH} 7 \cdot 5)$. The $\mathrm{pH}$ range for growth was determined in twofold diluted nutrient broth (NB; Difco) supplemented with $1 \%(\mathrm{v} / \mathrm{v})$ Hutner's mineral base (Cohen-Bazire et al., 1957) that was adjusted to various $\mathrm{pH}$ values (initial $\mathrm{pH} 4.5-11.5$ at intervals of $0.5 \mathrm{pH}$ units). The $\mathrm{pH}$ of twofold diluted $\mathrm{NB}$ was adjusted prior to sterilization to various levels by the addition of $\mathrm{HCl}$ and $\mathrm{Na}_{2} \mathrm{CO}_{3}$ (below pH 10.5) or $\mathrm{KOH}$ (above $\mathrm{pH} 10 \cdot 5$ ). Growth under 
anaerobic conditions was determined after incubation in an anaerobic chamber on twofold diluted NA ( $\mathrm{pH} 7 \cdot 5)$ and on twofold diluted NA ( $\mathrm{pH} 7 \cdot 5)$ supplemented with nitrate, both of which had been prepared anaerobically using nitrogen. Catalase and oxidase activities and hydrolysis of casein, gelatin, hypoxanthine, starch, Tweens 20, 40, 60 and 80, tyrosine, urea and xanthine were determined as described by Cowan \& Steel (1965). Hydrolysis of aesculin and nitrate reduction were studied as described previously (Lanyi, 1987). Utilization of substrates as sole carbon and energy sources was tested as described by Baumann \& Baumann (1981) supplemented with $2 \%$ (v/v) Hutner's mineral base (Cohen-Bazire et al., 1957) and $1 \%(\mathrm{v} / \mathrm{v})$ vitamin solution (Staley, 1968). Sensitivity to antibiotics was tested using antibiotic discs containing the following concentrations: polymyxin B, $100 \mathrm{U}$; streptomycin, $50 \mu \mathrm{g}$; penicillin G, $20 \mathrm{U}$; chloramphenicol, $100 \mu \mathrm{g}$; ampicillin, $10 \mu \mathrm{g}$; cephalothin, $30 \mu \mathrm{g}$; gentamicin, $30 \mu \mathrm{g}$; novobiocin, $5 \mu \mathrm{g}$; erythromycin, $15 \mu \mathrm{g}$; tetracycline, $30 \mu \mathrm{g}$. Enzyme activity was determined by using the API ZYM system (bioMérieux) with a modification that $0 \cdot 1 \mathrm{M}$ phosphate buffer $(\mathrm{pH} \mathrm{7 \cdot 5)}$ was used to prepare the cell suspension of strain KSL- $134^{\mathrm{T}}$. Other physiological and biochemical tests were performed with the API 20E system (bioMérieux).

Cell biomass for isoprenoid quinone analysis and for DNA extraction was obtained by cultivation at $30^{\circ} \mathrm{C}$ in twofold diluted NB ( $\mathrm{pH} 7 \cdot 5)$ supplemented with $1 \%(\mathrm{v} / \mathrm{v})$ Hutner's mineral base (Cohen-Bazire et al., 1957). Menaquinones were extracted according to the method of Komagata \& Suzuki (1987) and analysed using reversed-phase HPLC and a YMC ODS-A $(250 \times 4.6 \mathrm{~mm})$ column. Chromosomal DNA was isolated and purified according to the method described by Yoon et al. (1996), with the exception that ribonuclease $\mathrm{T} 1$ was treated in combination with ribonuclease A to minimize contamination with RNA. For fatty acid methyl ester analysis, cell mass of strain KSL-134 ${ }^{\mathrm{T}}$ was harvested from agar plates after incubation for 5 days on twofold diluted NA (pH 7.5) at $30^{\circ} \mathrm{C}$. The fatty acid methyl esters were extracted and prepared according to the standard protocol of the MIDI/Hewlett Packard Microbial Identification System (Sasser, 1990). The DNA G + C content was determined by the method of Tamaoka \& Komagata (1984) with a modification that DNA was hydrolysed and the resultant nucleotides were analysed by reversed-phase HPLC. The 16S rRNA gene was amplified by PCR using two universal primers as described previously (Yoon et al., 1998). Sequencing of the amplified 16S rRNA gene and phylogenetic analysis were performed as described by Yoon et al. (2003). DNA-DNA hybridization was performed fluorometrically by the method of Ezaki et al. (1989) using photobiotin-labelled DNA probes and microdilution wells. Hybridization was performed with five replications for each sample. The highest and lowest values obtained in each sample were excluded, and the means of the remaining three values were quoted as DNA-DNA relatedness values.

Morphological, cultural, physiological and biochemical characteristics of strain KSL- $134^{\mathrm{T}}$ are given in the species description (see later) or are shown in Table 1. The 16S rRNA gene sequence of strain KSL- $134^{\mathrm{T}}$ determined in this study comprised 1509 nucleotides, representing approximately $96 \%$ of the Escherichia coli $16 \mathrm{~S}$ rRNA gene sequence. Comparative 16S rRNA gene sequence analyses showed that strain KSL- $134^{\mathrm{T}}$ falls within the radiation of the cluster comprising Paenibacillus species (Fig. 1). Strain KSL-134 ${ }^{\mathrm{T}}$ exhibited 16S rRNA gene sequence similarity levels of 90.4\% (Paenibacillus nematophilus) to $96.5 \%$ ( $P$. agarexedens) with respect to the type strains of Paenibacillus species with validly published names.

The results obtained from chemotaxonomic analyses were in agreement with the results of $16 \mathrm{~S}$ rRNA gene sequence analysis and phylogenetic inference. Strain KSL-134 ${ }^{\mathrm{T}}$ contained meso-diaminopimelic acid as the diagnostic diamino acid in the cell-wall peptidoglycan. The predominant isoprenoid quinone found in strain KSL-134 ${ }^{\mathrm{T}}$ was unsaturated menaquinone with seven isoprene units (MK-7). Strain KSL- $134^{\mathrm{T}}$ had a cellular fatty acid profile that contained large amounts of branched and straight-chain fatty

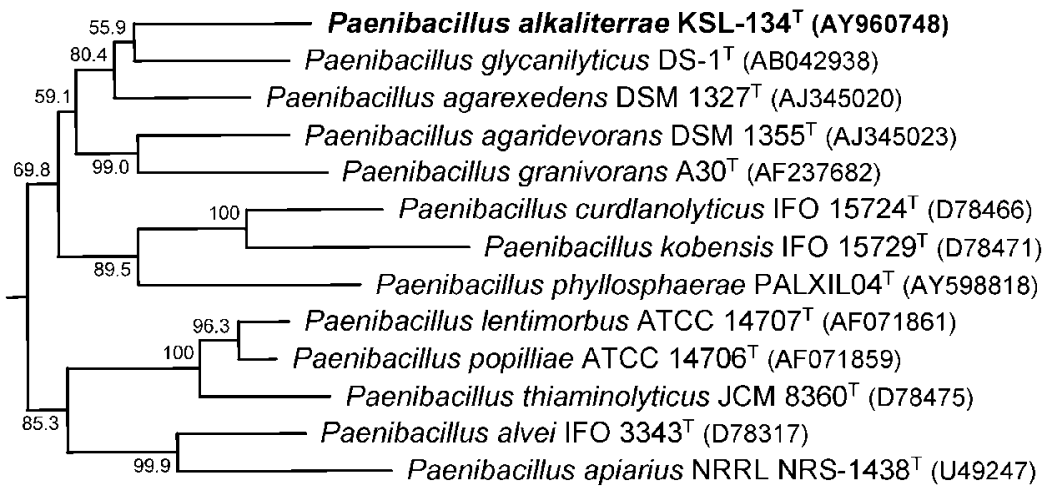

0.01
Fig. 1. Neighbour-joining tree based on $16 \mathrm{~S}$ rRNA gene sequence data showing the phylogenetic positions of strain $\mathrm{KSL}-134^{\top}$ and representatives of the genus Paenibacillus. Bootstrap values (1000 replications) are shown as percentages at each node only if they are $50 \%$ or greater. Scale bar, 0.01 substitutions per nucleotide position. The tree from which Fig. 1 was taken is available as supplementary data in IJSEM Online. 
Table 1. Differential phenotypic characteristics of Paenibacillus alkaliterrae sp. nov. and phylogenetically related Paenibacillus species

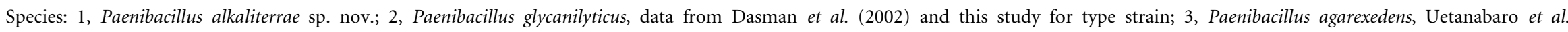

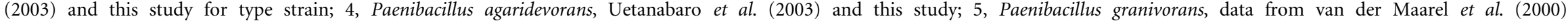

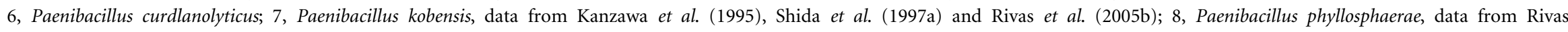

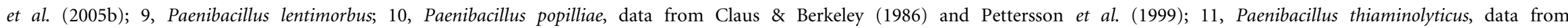

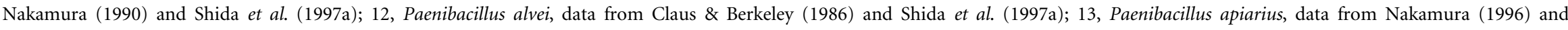

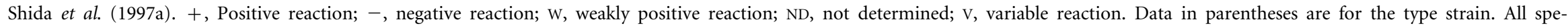
cies are positive for motility (or not determined) and formation of swollen sporangia, and negative for $\mathrm{H}_{2} \mathrm{~S}$ production (or not determined).

\begin{tabular}{|c|c|c|c|c|c|c|c|c|c|c|c|c|c|}
\hline Characteristic & 1 & 2 & 3 & 4 & 5 & 6 & 7 & 8 & 9 & 10 & 11 & 12 & 13 \\
\hline Gram stain & + & + & V or - & V or - & + & + & + & $\mathrm{V}$ & V or - & $\mathrm{V}$ or - & + & ND & $\mathrm{V}$ \\
\hline Flagellation* & $\mathrm{P}$ & $\operatorname{Pr}$ & ND & ND & $\operatorname{Pr}$ & $\operatorname{Pr}$ & $\operatorname{Pr}$ & Pr & ND & ND & ND & $\mathrm{ND}$ & ND \\
\hline Colony colour $\dagger$ & Ivory & $\begin{array}{l}\text { Pinkish } \\
\text { yellow }\end{array}$ & Whitish & Whitish & $\mathrm{ND}$ & $\mathrm{ND}$ & $\mathrm{ND}$ & $\begin{array}{l}\text { Whitish } \\
\text { cream }\end{array}$ & $\mathrm{ND}$ & $\mathrm{ND}$ & $\begin{array}{c}\text { Non- } \\
\text { pigmented }\end{array}$ & $\mathrm{ND}$ & $\begin{array}{c}\text { Non- } \\
\text { pigmented }\end{array}$ \\
\hline Anaerobic growth & - & - & - & - & - & - & - & + & + & + & + & + & + \\
\hline Oxidase & + & - & + & + & - & - & - & + & $(-)$ & $(-)$ & + & $\mathrm{ND}$ & - \\
\hline Catalase & + & + & + & + & + & + & + & + & - & - & + & + & + \\
\hline Urease & - & - & - & - & ND & + & + & - & - & $\mathrm{ND}$ & - & - & + \\
\hline Anaerobic growth & - & - & - & - & - & - & - & + & + & + & + & + & + \\
\hline Nitrate reduction & - & - & - & - & + & + & + & + & - & - & + & - & + \\
\hline Growth at $\mathrm{pH} 5 \cdot 7$ & - & + & - & - & - & $\mathrm{ND}$ & $\mathrm{ND}$ & ND & - & - & - & - & + \\
\hline $\begin{array}{l}\text { Growth at } 5 \%(\mathrm{w} / \mathrm{v}) \\
\mathrm{NaCl}\end{array}$ & - & - & - & - & - & - & - & - & - & - & V & $\mathrm{V}$ & + \\
\hline Growth at $40^{\circ} \mathrm{C}$ & - & + & $\mathrm{V}(-)$ & - & + & $\mathrm{ND}$ & ND & - & - & - & + & $\mathrm{ND}$ & + \\
\hline Production of indole & - & - & - & - & - & - & - & - & - & - & + & + & - \\
\hline V-P reaction & - & - & - & - & - & - & - & - & - & - & - & + & - \\
\hline \multicolumn{14}{|l|}{ Hydrolysis of: } \\
\hline Agar & - & $\mathrm{ND}$ & + & + & $\mathrm{ND}$ & $\mathrm{ND}$ & $\mathrm{ND}$ & $\mathrm{ND}$ & $\mathrm{ND}$ & $\mathrm{ND}$ & $\mathrm{ND}$ & $\mathrm{ND}$ & ND \\
\hline Casein & - & - & - & - & - & - & - & - & - & - & + & + & + \\
\hline Gelatin & - & - & - & - & - & $\mathrm{ND}$ & $\mathrm{ND}$ & $\mathrm{ND}$ & - & - & $\mathrm{ND}$ & + & $\mathrm{ND}$ \\
\hline Starch & + & + & + & $+1-\ddagger$ & + & + & + & + & - & - & + & + & + \\
\hline Tween 80 & + & - & - & - & $\mathrm{ND}$ & $\mathrm{ND}$ & $\mathrm{ND}$ & $\mathrm{ND}$ & $\mathrm{ND}$ & $\mathrm{ND}$ & - & ND & - \\
\hline Tyrosine & - & - & $\mathrm{V}(+)$ & - & - & $\mathrm{ND}$ & $\mathrm{ND}$ & $\mathrm{ND}$ & - & - & + & $\mathrm{V}$ & + \\
\hline \multicolumn{14}{|l|}{ Utilization of: } \\
\hline D-Fructose & + & + & $(-)$ & $(-)$ & $\mathrm{ND}$ & + & - & + & $\mathrm{ND}$ & ND & $\mathrm{ND}$ & $\mathrm{ND}$ & $\mathrm{ND}$ \\
\hline D-Mannose & + & + & $(-)$ & $(-)$ & $\mathrm{ND}$ & - & - & $\mathrm{W}$ & $\mathrm{ND}$ & $\mathrm{ND}$ & ND & ND & $\mathrm{ND}$ \\
\hline D-Xylose & + & + & $(+)$ & $(-)$ & $\mathrm{ND}$ & $\mathrm{ND}$ & $\mathrm{ND}$ & $\mathrm{ND}$ & $\mathrm{ND}$ & $\mathrm{ND}$ & $\mathrm{ND}$ & ND & $\mathrm{ND}$ \\
\hline Acetate & - & - & $(-)$ & $(-)$ & - & - & - & ND & $\mathrm{ND}$ & $\mathrm{ND}$ & + & $\mathrm{ND}$ & ND \\
\hline Citrate & - & - & $(-)$ & $(-)$ & - & - & - & - & - & - & + & - & + \\
\hline L-Malate & - & - & $(-)$ & $(-)$ & $\mathrm{ND}$ & - & - & - & $\mathrm{ND}$ & $\mathrm{ND}$ & + & ND & $\mathrm{ND}$ \\
\hline Succinate & + & - & $(-)$ & $(-)$ & $\mathrm{ND}$ & - & - & $\mathrm{ND}$ & $\mathrm{ND}$ & $\mathrm{ND}$ & + & ND & $\mathrm{ND}$ \\
\hline
\end{tabular}




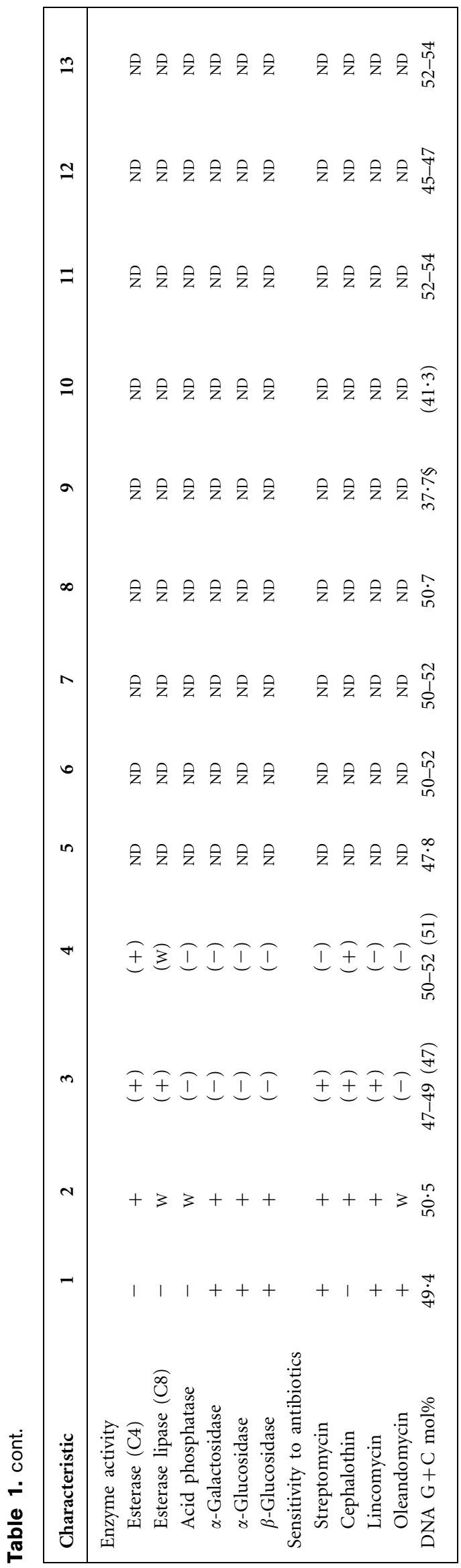

acids; the components $(>1 \%)$ were anteiso- $\mathrm{C}_{15: 0}(46 \cdot 3 \%)$, $\mathrm{C}_{16: 0}(17 \cdot 8 \%)$, iso- $\mathrm{C}_{16: 0}(10 \cdot 7 \%), \mathrm{C}_{18: 0}(5 \cdot 2 \%), \mathrm{C}_{15: 0}$ $(3 \cdot 8 \%)$, anteiso- $\mathrm{C}_{17: 0}(3 \cdot 7 \%), \mathrm{C}_{16: 0} 2-\mathrm{OH}(3 \cdot 4 \%)$, iso$\mathrm{C}_{14: 0}(3 \cdot 3 \%)$, iso- $\mathrm{C}_{15: 0}(2 \cdot 3 \%), \mathrm{C}_{14: 0}(2 \cdot 2 \%)$ and $\mathrm{C}_{16: 1} \omega 11 c(1 \cdot 5 \%)$. This fatty acid profile was similar to those of Paenibacillus species (Shida et al., 1997a; Rivas et al., 2005a, b, c; Takeda et al., 2005; Sánchez et al., 2005). The DNA G + C content of strain KSL- $134^{\mathrm{T}}$ was $49 \cdot 4 \mathrm{~mol} \%$.

The phylogenetic distinctiveness was sufficient to categorize strain KSL- $134^{\mathrm{T}}$ as a member of a species that is distinct from the previously recognized Paenibacillus species (Stackebrandt \& Goebel, 1994). There were differences between strain KSL- $134^{\mathrm{T}}$ and several phylogenetically related Paenibacillus species in phenotypic characteristics (Table 1). Mean levels of DNA-DNA relatedness were low $(9-17 \%)$ enough to genetically distinguish strain KSL- $134^{\mathrm{T}}$ from the type strains of three phylogenetically and physiologically related Paenibacillus species, P. glycanilyticus, P. agarexedens and P. agaridevorans (Wayne et al., 1987). Therefore, on the basis of the data presented, strain KSL- $134^{\mathrm{T}}$ should be classified in the genus Paenibacillus as a member of a novel species, for which the name Paenibacillus alkaliterrae sp. nov. is proposed.

\section{Description of Paenibacillus alkaliterrae sp. nov.}

Paenibacillus alkaliterrae (al.ka.li.ter' rae. N.L. n. alkali alkali; L. gen. n. terrae of the soil or earth; N.L. gen. n. alkaliterrae of high-pH soil).

Cells are aerobic rods, $0 \cdot 4-0.5 \times 1 \cdot 5-3.0 \mu \mathrm{m}$. Grampositive. Motile by means of a single polar flagellum. Central or subterminal ellipsoidal endospores are observed in swollen sporangia. Colonies on twofold diluted NA $(\mathrm{pH} 7 \cdot 5)$ are circular to slightly irregular, smooth, sticky, glistening, raised, ivory-coloured and $2 \cdot 0-4 \cdot 0 \mathrm{~mm}$ in diameter after 5 days incubation at $30^{\circ} \mathrm{C}$. Optimal temperature for growth is $30^{\circ} \mathrm{C}$; growth occurs at 10 and $37^{\circ} \mathrm{C}$, but not at 4 and $38^{\circ} \mathrm{C}$. Optimal $\mathrm{pH}$ for growth is $7 \cdot 5$; growth occurs at $\mathrm{pH} 7 \cdot 0$ and $9 \cdot 5$, but not at $\mathrm{pH} 6 \cdot 5$ and $10 \cdot 0$. Anaerobic growth does not occur on twofold diluted NA $(\mathrm{pH} 7 \cdot 5)$ and on twofold diluted NA ( $\mathrm{pH} 7 \cdot 5)$ supplemented with nitrate. Aesculin is hydrolysed, but Tweens 20, 40 and 60, hypoxanthine and xanthine are not. DGlucose, D-fructose, D-galactose, D-cellobiose, D-mannose, D-trehalose, D-xylose, L-arabinose, sucrose, maltose and salicin are utilized, but benzoate, pyruvate, formate and L-glutamate are not. Arginine dihydrolase, lysine decarboxylase, ornithine decarboxylase and tryptophan deaminase are absent. In assays with API ZYM, alkaline phosphatase, lipase (C14), leucine arylamidase, valine arylamidase, cystine arylamidase, trypsin, $\alpha$-chymotrypsin, naphthol-AS-BI-phosphohydrolase, $\beta$-glucuronidase, $N$ acetyl- $\beta$-glucosaminidase, $\alpha$-mannosidase and $\alpha$-fucosidase are absent. Sensitive to polymyxin B, penicillin G, chloramphenicol, gentamicin, novobiocin, tetracycline and kanamycin, but not to ampicillin. The cell-wall peptidoglycan 
contains meso-diaminopimelic acid. The predominant menaquinone is MK-7. The major fatty acid is anteiso$\mathrm{C}_{15: 0}$. The DNA G+C content is $49 \cdot 4 \mathrm{~mol} \%$ (determined by HPLC). Other phenotypic characteristics are given in Table 1.

The type strain, KSL-134 ${ }^{\mathrm{T}}\left(=\mathrm{KCTC} 3956^{\mathrm{T}}=\mathrm{DSM} 17040^{\mathrm{T}}\right.$ ), was isolated from an alkaline soil in Kwangchun, Korea.

\section{Acknowledgements}

This work was supported by the 21C Frontier program of Microbial Genomics and Applications (grant MG02-0401-001-1-0-0) from the Ministry of Science and Technology (MOST) of the Republic of Korea.

\section{References}

Ash, C., Priest, F. G. \& Collins, M. D. (1993). Molecular identification of rRNA group 3 bacilli (Ash, Farrow, Wallbanks, and Collins) using a PCR probe test. Proposal for the creation of a new genus Paenibacillus. Antonie van Leeuwenhoek 64, 253-260.

Baumann, L. \& Baumann, P. (1981). The marine Gram-negative eubacteria; genera Photobacterium, Beneckea, Alteromonas, Pseudomonas, and Alcaligenes. In The Prokaryotes. A Handbook on Habitats, Isolation, and Identification of Bacteria, pp. 1302-1330. Edited by M. P. Starr, H. Stolp, H. G. Trüper, A. Balows \& H. G. Schlegel. Berlin: Springer.

Claus, D. \& Berkeley, R. C. W. (1986). Genus Bacillus Cohn 1872. In Bergey's Manual of Systematic Bacteriology, vol. 2, pp. 1105-1140. Edited by P. H. A. Sneath, N. S. Mair, M. E. Sharpe \& J. G. Holt. Baltimore: Williams \& Wilkins.

Cohen-Bazire, G., Sistrom, W. R. \& Stanier, R. Y. (1957). Kinetic studies of pigment synthesis by nonsulfur purple bacteria. J Cell Comp Physiol 49, 25-68.

Cowan, S. T. \& Steel, K. J. (1965). Manual for the Identification of Medical Bacteria. London: Cambridge University Press.

Dasman, Kajiyama, S., Kawasaki, H., Yagi, M., Seki, T., Fukusaki, E. \& Kobayashi, A. (2002). Paenibacillus glycanilyticus sp. nov., a novel species that degrades heteropolysaccharide produced by the cyanobacterium Nostoc commune. Int J Syst Evol Microbiol 52, 1669-1674.

Ezaki, T., Hashimoto, Y. \& Yabuuchi, E. (1989). Fluorometric deoxyribonucleic acid-deoxyribonucleic acid hybridization in microdilution wells as an alternative to membrane filter hybridization in which radioisotopes are used to determine genetic relatedness among bacterial strains. Int J Syst Bacteriol 39, 224-229.

Heyndrickx, M., Vandemeulebroecke, K., Scheldeman, B., Kersters, K., De Vos, P., Logan, N. A., Aziz, A. M., Ali, N. \& Berkeley, R. C. W. (1996). A polyphasic reassessment of the genus Paenibacillus, reclassification of Bacillus lautus (Nakamura 1984) as Paenibacillus lautus comb. nov. and of Bacillus peoriae (Montefusco et al. 1993) as Paenibacillus peoriae comb. nov., and emended descriptions of $P$. lautus and of P. peoriae. Int J Syst Bacteriol 46, 988-1003.

Kanzawa, Y., Harada, A., Takeuchi, M., Yokota, A. \& Harada, T. (1995). Bacillus curdlanolyticus sp. nov. and Bacillus kobensis sp. nov., which hydrolyze resistant curdlan. Int J Syst Bacteriol 45, 515-521.

Komagata, K. \& Suzuki, K. (1987). Lipids and cell-wall analysis in bacterial systematics. Methods Microbiol 19, 161-203.

Lanyi, B. (1987). Classical and rapid identification methods for medically important bacteria. Methods Microbiol 19, 1-67.
Nakamura, L. K. (1990). Bacillus thiaminolyticus sp. nov., nom. rev. Int J Syst Bacteriol 40, 242-246.

Nakamura, L. K. (1996). Paenibacillus apiarius sp. nov. Int J Syst Bacteriol 46, 688-693.

Pettersson, B., Rippere, K. E., Yousten, A. A. \& Priest, F. G. (1999). Transfer of Bacillus lentimorbus and Bacillus popilliae to the genus Paenibacillus with emended descriptions of Paenibacillus lentimorbus comb. nov. and Paenibacillus popilliae comb. nov. Int J Syst Bacteriol 49, 531-540.

Rivas, R., Mateos, P. F., Martínez-Molina, E. \& Velázquez, E. (2005a). Paenibacillus xylanilyticus sp. nov., an airborne xylanolytic bacterium. Int J Syst Evol Microbiol 55, 405-408.

Rivas, R., Mateos, P. F., Martínez-Molina, E. \& Velázquez, E. (2005b). Paenibacillus phyllosphaerae sp. nov., a xylanolytic bacterium isolated from phyllosphere of Phoenix dactylifera. Int J Syst Evol Microbiol 55, 743-746.

Rivas, R., Gutiérrez, C., Abril, A., Mateos, P. F., Martínez-Molina, E., Ventosa, A. \& Velázquez, E. (2005c). Paenibacillus rhizosphaerae sp. nov., isolated from the rhizosphere of Cicer arietinum. Int J Syst Evol Microbiol 55, 1305-1309.

Roux, V. \& Raoult, D. (2004). Paenibacillus massiliensis sp. nov., Paenibacillus sanguinis sp. nov. and Paenibacillus timonensis sp. nov., isolated from blood cultures. Int J Syst Evol Microbiol 54, 1049-1054.

Sánchez, M. M., Fritze, D., Blanco, A., Spröer, C., Tindall, B. J., Schumann, P., Kroppenstedt, R. M., Diaz, P. \& Pastor, F. I. J. (2005). Paenibacillus barcinonensis sp. nov., a xylanase-producing bacterium isolated from a rice field in the Ebro River delta. Int J Syst Evol Microbiol 55, 935-939.

Sasser, M. (1990). Identification of Bacteria by Gas Chromatography of Cellular Fatty Acids. Newark, DE: MIDI.

Shida, O., Takagi, H., Kadowaki, K., Nakamura, L. K. \& Komagata, K. (1997a). Transfer of Bacillus alginolyticus, Bacillus chondroitinus, Bacillus curdlanolyticus, Bacillus glucanolyticus, Bacillus kobensis, and Bacillus thiaminolyticus to the genus Paenibacillus and emended description of the genus Paenibacillus. Int J Syst Bacteriol 47, 289-298.

Shida, O., Takagi, H., Kadowaki, K., Nakamura, L. K. \& Komagata, K. (1997b). Emended description of Paenibacillus amylolyticus and description of Paenibacillus illinoisensis sp. nov. and Paenibacillus chibensis sp. nov. Int J Syst Bacteriol 47, 299-306.

Stackebrandt, E. \& Goebel, B. M. (1994). Taxonomic note: a place for DNA-DNA reassociation and 16S rRNA sequence analysis in the present species definition in bacteriology. Int J Syst Bacteriol 44, 846-849.

Staley, J. T. (1968). Prosthecomicrobium and Ancalomicrobium: new prosthecate freshwater bacteria. J Bacteriol 95, 1921-1942.

Takeda, M., Suzuki, I. \& Koizumi, J. (2005). Paenibacillus hodogayensis sp. nov., capable of degrading the polysaccharide produced by Sphaerotilus natans. Int J Syst Evol Microbiol 55, 737-741.

Tamaoka, J. \& Komagata, K. (1984). Determination of DNA base composition by reverse-phase high-performance liquid chromatography. FEMS Microbiol Lett 25, 125-128.

Uetanabaro, A. P., Wahrenburg, C., Hunger, W., Pukall, R., Spröer, C., Stackebrandt, E., de Canhos, V. P., Claus, D. \& Fritze, D. (2003). Paenibacillus agarexedens sp. nov., nom. rev., and Paenibacillus agaridevorans sp. nov. Int J Syst Evol Microbiol 53, 1051-1057.

van der Maarel, M. J. E. C., Veen, A. \& Wijbenga, D. J. (2000). Paenibacillus granivorans sp. nov., a new Paenibacillus species which degrades native potato starch granules. Syst Appl Microbiol 23, 344-348.

Wayne, L. G., Brenner, D. J., Colwell, R. R. \& 9 other authors (1987). International Committee on Systematic Bacteriology. Report of the 
ad hoc committee on reconciliation of approaches to bacterial systematics. Int J Syst Bacteriol 37, 463-464.

Yoon, J.-H., Kim, H., Kim, S.-B., Kim, H.-J., Kim, W. Y., Lee, S. T., Goodfellow, M. \& Park, Y.-H. (1996). Identification of Saccharomonospora strains by the use of genomic DNA fragments and rRNA gene probes. Int J Syst Bacteriol 46, 502-505.
Yoon, J.-H., Lee, S. T. \& Park, Y.-H. (1998). Inter- and intraspecific phylogenetic analysis of the genus Nocardioides and related taxa based on 16S rRNA gene sequences. Int J Syst Bacteriol 48, 187-194.

Yoon, J.-H., Kang, K. H. \& Park, Y.-H. (2003). Psychrobacter jeotgali sp. nov., isolated from jeotgal, a traditional Korean fermented seafood. Int J Syst Evol Microbiol 53, 449-454. 